\title{
INOVASI PEMBELAJARAN ALJABAR RING MELALUI LESSON STUDY
}

\author{
Karsoni Berta Dinata *)
}

\begin{abstract}
Subject Algebra Ring or Algebra Abstract has abstract characteristics and requires a variety of supporting knowledge to learn it. Abstract characteristic in the material of algebra ring requires a lecturer to innovate creatively, pack material to be easily understood by the students and design the learning that can improve the students' capabilities. Learning innovation should be done continuously by reflecting the effectiveness of the learning that has been done. Lesson Study facilitates the quality of learning to be improved through the cycle 1) Plan (Plan), 2) do (perform), and see (reflect), which is done collaboratively and with the collegial principle. Lesson Study gives a positive impact so that the dynamic mathematics learning can be implemented.
\end{abstract}

Key words: algebra ring, learning, lesson study, and collaborative

\section{PENDAHULUAN}

Salah satu misi Program Studi Pendidikan Matematika STKIP Muham madiyah kotabumi adalah terselenggaranya pembelajaran Matematika yang dinamis dan kondusif di lingkungan STKIP Muhammadiyah Kotabumi Lampung. Citacita untuk mewujudkan pembelajaran yang dinamis dapat dilakukan dengan selalu berupaya memperbaiki mutu pembelajaran.

Aljabar Ring merupakan salah satu mata kuliah pada program studi Matematika yang merupakan kelanjutan dari mata kuliah aljabar grup. Mata kuliah aljabar ring mempunyai karakteristik abstrak yang membutuhkan penalaran deduktif dalam memahami setiap teoremanya. Selain itu diperlukan beberapa pengetahuan prasyarat dalam mempelajarinya seperti pengetahuan terkait konsep himpunan, logika, aljabar, teori bilangan dan aljabar linear.

Sifat abstrak pada materi aljabar ring mengharuskan dosen untuk secara kreatif mengemas materi pada suatu pembelajaran sehingga materi tersebut dipahami oleh mahasiswa, serta memikirkan rancangan pembelajaran yang tepat yang akan dilaksanakan. Perbaikan proses pembelajaran perlu dilakukan secara kontinu agar mutu pembelajaran semakin meningkat.

Usaha atau upaya untuk senantiasa memperbaiki mutu pembelajaran dapat dilakukan melalui Lesson study. Ide atau gagasan Lesson Study pertama kali muncul di Jepang lebih dari 20 tahun yang lalu. Tujuan dari Lesson Study, yaitu untuk pengembangan profesionalisme guru. Menurut Hendayana dkk (2006:10) Lesson Study merupakan suatu model pembinaan profesi pendidikan melalui 
pengkajian pembelajaran secara kolaboratif dan berkelanjutan berlandaskan prinsipprinsip kolegalitas dan mutual Learning untuk membangun komunitas belajar.

Friedkin (2005) menyatakan Lesson Studi sebagai proses yang melibatkan guruguru yang bekerja sama dalam merencanakan, mengobservasi, menganalisis dan memperbaiki pembelajaran. Dengan demikian Lesson Studi bukanlah suatu metode, pendekatan atau strategi pembelajaran. Namun, lesson study merupakan suatu kegiatan yang melibatkan beberapa guru/dosen yang saling bekerja sama secara kolaboratif dalam hal merencanakan, menganalisis, dan memperbaiki suatu pembelajaran yang dapat menggunakan ber bagai metode, strategi atau pendekatan pembelajaran.

Menurut Mahmudi (2009:2) dalam melaksanakan kegiatan Lesson Study ada beberapa tahapan yang harus dilakukan yaitu: 1) Perencanaan (Plan), 2) Pelaksanaan (Do), 3) Refleksi (See). Ketiga tahapan ini akan diterapkan dalam penelitian untuk melihat proses pembelajaran dan perbaikan proses pembelajaran.

Pembelajaran yang baik, yaitu pembelajaran yang berpusat pada siswa/mahasiswa. Dengan menekankan pada keaktifan mahasiswa selama proses pembelajaran sehingga diharapkan materi yang dipelajari oleh mahasiswa semakin bermakna.
Pembelajaran di abad 21 menekankan penguasaan 4 soft skills: berpikir kritis, kolaborasi, kreativitas, dan komunikasi. Seseorang yang memiliki kemampuan berpikir kritis akan sulit tergoda dengan tawaran yang tidak masuk akal sehat. Contoh banyak masyarakat yang tidak berpikir kritis mengakibatkan tertipu tawaran investasi dengan bunga besar.

Tugas dosen, yaitu melatih kemampuan berpikir kritis melalui pemberian persoalan menantang untuk dipecahkan mahasiswa. Dengan persoalan menantang, memicu mahasiswa nuntuk bertanya kepada temannya sehingga terjadi saling mendengar dan saling belajar (pembelajaran kolaboratif).

Kreativitas terbangun apabila ada tantangan yang harus dipecahkan melalui kolaborasi, mahasiswa akan bertukar ide untuk solusinya. Kemampuan komunikasi yang efektif merupakan modal untuk mampu menjual idenya.

Berdasarkan pengalaman peneliti, pembelajaran di Prodi matematika STKIP Muhammadiyah Kotabumi sudah berupaya untuk mengembangkan kemampuan berpikir kritis, kerja sama, kreativitas, dan komunikasi. Hal ini dapat dilihat pada pemberian soal atau tugas yang cukup menantang, diskusi mahasiswa secara berkelompok, berupaya menjelaskan materi presentasi kelompok yang diharapkan mampu mengembangkan kemampuan komunikasi mahasiswa, serta pemberian beberapa tugas 
yang merang sang mahasiswa untuk mengembangkan kreativitasnya.

Upaya yang telah dilakukan untuk mengembangkan kemampuan-kemampuan mahasiswa tersebut tampaknya masih perlu dilakukan secara terus menerus agar tujuan pembelajaran tercapai. Masih ada beberapa celah bahkan kekurangan yang perlu dilakukan.

Selama ini pembelajaran dilakukan secara individual oleh masing-masing dosen pengampu mata kuliah. Proses perencanaan, pelaksanaan, dan evaluasi dilakukan secara mandiri. Dengan demikian, dalam pelaksanaan pembelajaran terkadang dosen kesulitan dalam memperhatikan kemajuan belajar setiap mahasiswa, selain itu dosen juga cenderung melihat dari perspektif individu dalam mengevaluasi proses pembelajaran, sehingga beberapa celah kekurangan selama proses pembelajaran luput dari perhatian dosen. Oleh karena itu, dianggap penting dosen tidak secara individual, tetapi secara kolaborasi bekerja sama dengan beberapa dosen lain untuk berperan serta dalam memperbaiki proses pembelajaran.

Melalui Lesson Studi, dosen di- fasilitasi secara kolaboratif bekerja sama dosen lain berusaha meningkatkan mutu proses pembelajaran dengan tahapan plan, do, dan see berdasarkan prinsip mutual lerning berkelanjutan.
Kegiatan Kolaboratif antardosen sangat bermanfaat. Dosen pengampu mata kuliah (dosen model) akan berupaya semaksimal mungkin melakukan kegiatan perencanaan pembelajaran, dosen lain selain dosen model (dosen observer) akan melihat perencanaan yang telah dilakukan oleh dosen model dan berusaha untuk membantu memperbaiki. Proses kerja sama ini akan sangat bermanfaat dalam menyempurnakan perencanaan pembelajaran.

Pada proses pelaksanaan, dosen model akan berupaya semaksimal mungkin agar realisasi proses pembelajaran sesuai dengan apa yang telah direncanakan. Di lain pihak, dosen observer akan berupaya untuk mengamati proses pembelajaran. Dalam kegiatan pelaksanaan, dosen observer tidak boleh mengganggu proses pembelajaran, observasi hanya difokuskan pada kegiatan mahasiswa belajar.

Proses akhir, yaitu tahapan refleksi. Pada tahapan ini dosen model beserta dosen observer melakukan kegiatan refleksi. Pada kegiatan ini dosen model akan mereview atau mengulas kembali pelaksaan pembelajaran yang telah dilakukan, kemudian observer akan memberikan masukan-masukan positif agar mutu pembelajaran selanjutnya diharapkan akan lebih baik.

Siklus perencanaan, pelaksanaan, dan refleksi akan dilakukan berulang. Dengan dilaksanakannya siklus ini celah atau kekurangan selama proses pembelajaran 
dapat diatasi karena dilakukan secara berurutan. Setiap siklus akan dijelaskan kolaboratif sehingga membuat dosen model kegiatan Plan, do, dan see.

terbantu dalam upaya untuk selalu mengembangkan dan berinovasi agar mutu pembelajaran semakin meningkat.

\section{Siklus I}

\section{Plan}

Plan atau perencanaan dilakukan pada

\section{METODE}

Dalam penelitian ini digunakan model Lesson Studi berbasis Penelitian Tindakan Kelas (PTK) yang dimodifikasi. Menurut Subadi (2010) penelitian ini merupakan penelitian PTK dengan menerapkan teknikteknik yang telah dikembangkan dalam lesson study.

Penelitian ini menggunakan tahapan plan, do, dan see yang dilakukan dalam tiga siklus. Penelitian berupaya untuk melihat kefektifan pembelajaran pada matakuliah aljabar ring dengan memanfaatkan prinsipprinsip pada lesson study.

Penelitian dilakukan di kelas 5A Prodi Pendidikan matematika STKIP Muhammadiyah Tahun Akademik 2017/2018 yang berjumlah 22 mahasiswa, pada mata kuliah Aljabar Ring. Penelitian dimulai pada hari Senin tanggal 2 Oktober 2017 untuk siklus pertama, tanggal 9 Oktober 2017 untuk siklus kedua dan tanggal 16 Oktober 2017 untuk siklus yang ketiga. Setiap kegiatan dalam setiap siklus akan dijelaskan secara berurutan

\section{HASIL DAN PEMBAHASAN}

Hasil dan pembahasan dalam penelitian ini akan dijelaskan dalam setiap siklus secara tanggal 2 Oktober 2017. Kegiatan ini diikuti oleh 3 dosen observer yang akan melihat rencana pembelajaran yang telah dirancang oleh dosen model. Dalam kegiatan ini, secara umum dosen observer setuju dengan rancangan (Lesson Design) yang telah dibuat sehingga kegiatan dilanjutkan pada tahapan pelaksanaan.

\section{Do}

Do atau pelaksanaan dilakukan di dalam kelas. Pada kegiatan pelaksanaan, materi yang diajarkan, yaitu materi pengertiang Ring. Pembelajaran dilakukan secara diskusi kelompok dan tanya jawab. Penilaiaan dilakukan dengan menggunakan metode Asesment for Learning (AfL). Langkah awal yang dilakukan dosen, yaitu mengingat kembali materi aljabar grup yang telah dipelajari dan membentuk kelompok heterogen dalam kelas. Kemudian dosen memberikan sebuah contoh himpunan dengan suatu operasi tertentu. Kemudian mahasiswa diminta untuk mengerjakan perintah soal tersebut secara berkelompok. Soal yang diberikan cukup menantang, mahasiswa dianggap bisa mengerjakan soal karena hanya terkait operasi sederhana. Selanjutnya dosen 
bersama mahasiswa mengkaji aksioma terkait ring. Selanjutnya dosen meminta kelompok untuk mencari himpunan yang merupakan ring. Sebagai Jumping task setiap kelompok diberikan beberapa soal terkait dengan konsep ring

\section{See}

Kegiatan see atau refleksi dilaksanakan setelah kegiatan pelaksanaan. Dalam kegiatan ini beberapa observer mem berikan komentarnya berdasarkan hasil pengamatan atau observasi. Observer pertama memberikan masukan terkait beberapa anggota kelompok yang hanya pasif selama proses pmbelajaran. Beberapa kelompok aktif selama proses pembelajaran, sedangkan masih ada beberapa kelompok yang kurang aktif selama proses pem- belajaran. Observer kedua memberikan masukan atas pelaksanaan proses pembelajaran, observer dua menyatakan bahwa kelompok dibuat secara mendadak sehingga kelompok belum terlihat heterogen. Observer ketiga memberikan masukan bahwa dalam pembentukan kelompok masih terlihat sangat gaduh dan tidak rapi, sehingga menyulitkan dosen model memberikan bantuan saat mahasiswa berdiskusi kelompok.

\section{SIKLUS II}

Siklus ini merupakan kelanjutan dari siklus yang pertama. Hasil refleksi dari pembelajaran siklus pertama akan dijadikan dasar dalam memperbaiki siklus kedua. Berikut dijelaskan tahapan-tahapan pada siklus kedua.

\section{Plan}

Sebelum melakukan kegiatan plan pada siklus kedua, dilakukan perencanaan pembelajaran oleh dosen model dengan mempertimbangkan hasil refleksi pada siklus yang pertama. Permasalahan adanya anggota kelompok dan kelompok yang kurang aktif selama proses pembelajaran diduga disebabkan karena pembentukan kelompok yang kurang heterogen. Oleh karena itu direncanakan pada siklus kedua, kelompok dibuat heterogen berdasarkan kemampuan akademik berdasarkan data hasil belajar sebelumnya. Kelas direncanakan agar dikondisikan terlebih dahulu dengan menyusun kursi berdasarkan anggota kelompok, kursi yang tidak terpakai disusun secara rapi dibelakang kelas. Materi yang diajarkan pada siklus kedua masih menggunakan materi sebelumnya, yaitu pengertian ring. Metode dan assessment yang dilakukan sama seperti pada siklus pertama. Pada kegiatan plan dosen observer secara umum menyetujui lesson dosen yang telah dibuat oleh dosen model.

\section{Do}

Pada kegiatan ini, pembelajaran diawali dengan mengingat kembali konsep ring yang telah dipelajari sebelumnya. Selanjutnya 
setiap kelompok diminta untuk memberikan sebuah himpunan dengan dua buah operasi biner. Kelompok lain diminta menyelidiki apakan himpunan yang diberikan merupakan ring, proses ini dilakukan secara silang pada masing-masing kelompok. Setiap kelompok memberikan soal dan kelompok lain mengerjakan soal. Dosen bertindak sebagai fasilitator memfasilitasi diskusi dan memberikan bantuan kepada kelompok untuk menjawab soal. Kelompok yang telah selesai mengerjakan soal di depan dan mempresentasikan hasil jawabanya.

\section{See}

Pada tahapan ini dilakukan refleksi atas pelaksanaan yang telah dilakukan. Observer satu, menyatakan bahwa dari pertama dimulainya pembelajaran kelompok 1, 2, 4 dan 5 sudah mulai menunjukkan keaktifan selama proses pembelajaran, tetapi ada satu kelompok, yaitu kelompok 3 cenderung pasif, terkesan kerja anggota kelompok individual, dan jarang terlihat berdiskusi. Beberapa anggota kelompok terlihat hanya mencatat apa yang ada di papan tulis. Observer dua menyatakan, kelompok antusias dalam membuat soal, hampir semua kelompok aktif dalam pembelajaran tetapi ada kelompok 3 yang kurang antusisas selama proses pembelajaran. Secara umum masukan oleh observer dua hampir sama dengan observer 1 . Observer tiga menyampaikan hasil observasinya mengenai ketika pembelajaran sudah dimulai, masih banyak mahasiswa yang belum focus dalam mengikuti proses pembelajaran.

\section{Siklus III}

Siklus ini merupakan kelanjutan dari siklus yang kedua. Hasil refleksi dari pembelajaran siklus kedua akan dijadikan dasar dalam memperbaiki siklus kedua. Berikut dijelaskan tahapan-tahapan pada siklus ketiga.

\section{Plan}

Sebelum kegiatan plan dimulai dosen model merancang lesson design dan lembar kerja mahasiswa dengan mempertimbangkan hasil refleksi pada siklus 3. Setelah lesson design dan lembar kerja mahasiswa telah dibuat, dilakukanlah kegiatan plan pada siklus yang ketiga. Kegiatan ini dihadiri oleh dua observer. Dosen model menerangkan pembelajaran yang akan dilaksanakan sebagaimana yang tertuang dalam lesson design dan disetujui oleh para dosen observer.

\section{Do}

Pada kegiatan ini materi yang diajarkan adalah materi ring dengan elemen satuan dan ring komutatatif. Mahasiswa sudah terkondisi dalam kelompok seperti pembelajaran pada siklus II. Sebagai langkah awal dalam pembelajaran dosen membawa mahasiswa menganalisis kembali konsep ring dan membawa kepada konsep ring dengan elemen satuan dan ring komutatif. Setelah mahasiswa 
memahami definisi ring dengan elemen satuan dan ring komutatif mahasiswa diminta untuk kembali menganalisis ring yang telah dibuktikan sebelumnya apakah merupakan ring dengan elemen satuan dan ring komutatif. Penilaian yang dilakukan dengan menggunakan penilaian formatif dengan metode Asesment for learning (AfL) dengan tujuan apakah mahasiswa benar-benar sudah memahami konsep yang telah di- ajarkan atau belum, juga untuk mendiagnosis jika terjadi miskonsepdi dalam pemahaman konsep. Presentasi dilakukan oleh setiap kelompok dan diadakan diskusi antarkelompok mengenai jawaban dari kelompok yang presentasi.

\section{See}

Setelah kegiatan do dilaksanakan, dilaksanakanlah kegiatan refleksi untuk melihat kembali proses pembelajaran yang telah dilaksanakan. Secara umum, observer memberikan komentar positif terkait proses pembelajaran yang telah dilaksanakan. Meskipun pada awal pembelajaran ada kelompok yang kurang antusias, pada akhirnya kelompok tersebut menjadi aktif berdiskusi memecahkan permasalahan yang diberikan.

\section{PENUTUP}

Perbaikan mutu pembelajaran hendaknya selalu dilakukan secara terus menerus dan berkelanjutan. Melalui Lesson Studi perbaikan proses pembelajaran dapat dilakukan secara sistematis, tidak hanya dilakukan secara individual oleh dosen pengampu mata kuliah, tetapi bersama-sama dengan dosen lain secara kolaboratif. Melalui tahapan plan, do, dan see, kegiatan perbaikan dilakukan mulai dari perencanaan pembelajaran sampai pembelajaran selesai. Lesson study memberikan dampak yang positif agar terselenggaranya pembelajaran Matematika yang dinamis dan kondusif di lingkungan STKIP Muhammadiyah Kotabumi Lampung khususnya dalam mengajarkan mata kuliah Aljabar ring Program Studi Matematika.

\section{DAFTAR RUJUKAN}

Friedkin, Shelley. 2005. What is Lesson Study? (Online). Tersedia: http://www.lessonresearch.net/. (30 Oktober 2017)

Hendayana, S., dkk. (2006). Lesson Study: suatu Strategi untuk Meningkatkan Keprofesionalan Pendidikan (Pengalaman IMSTEP-JICA). Bandung UPI Press

Mahmudi, Ali. 2009. Mengembangkan Kompetensi Guru Melalui Lesson Study. Forum Kependidikan, vol. 28. No.2, hlm. 84-89

Subadi, Tjipto. 2010. Lesson Study Berbasis PTK (Penelitian Tindakan Kelas); Suatu Model Pembinaan Menuju Guru Profesional. Surakarta. BP-FKIP UMS. 